\title{
A New Species of Frog Allied to Fejervarya limnocharis from the Southern Ryukyus, Japan (Amphibia: Ranidae)
}

$\operatorname{AUTHOR}(S)$ :

Matsui, Masafumi; Toda, Mamoru; Ota, Hidetoshi

\section{CITATION:}

Matsui, Masafumi ... [et al]. A New Species of Frog Allied to Fejervarya limnocharis from the Southern Ryukyus, Japan (Amphibia: Ranidae). Current Herpetology 2007, 26(2): 65-79

\section{ISSUE DATE:}

2007-12

URL:

http://hdl.handle.net/2433/216832

RIGHT:

(C) 2007 by The Herpetological Society of Japan 


\title{
A New Species of Frog Allied to Fejervarya limnocharis from the Southern Ryukyus, Japan (Amphibia: Ranidae)
}

\author{
MASAFUMI MATSUI ${ }^{1 *}$, MAMORU TODA ${ }^{2}$, AND HIDETOSHI OTA ${ }^{3}$ \\ ${ }^{1}$ Graduate School of Human and Environmental Studies, Kyoto University, Sakyo-ku, \\ Kyoto 606-8501, JAPAN \\ ${ }^{2}$ Department of Zoology, Graduate School of Science, Kyoto University, Sakyo-ku, Kyoto \\ 606-8502, JAPAN \\ ${ }^{3}$ Tropical Biosphere Research Center, University of the Ryukyus, Nishihara, Okinawa \\ 903-0213, JAPAN
}

\begin{abstract}
The populations of a frog long identified as Fejervarya limnocharis from the Southern Ryukyus (=Sakishima in conventional regional name), Japan, considerably differ genetically and morphologically from the topotypic population of the species from Java. These Southern Ryukyu populations are therefore judged to represent a distinct biological species, which is described here as Fejervarya sakishimensis. This new species differs from $\boldsymbol{F}$. limnocharis in larger snout-vent length (SVL). Also, it is distinguished from the latter in shorter head and tibia, smaller eye and narrower internarial space, all relative to SVL, and larger ratio of the first toe length to the inner metatarsal tubercle. From $F$. multistriata, $F$. sakishimensis differs by relatively larger tympanum, wider head, upper eyelid and anterior and posterior spaces of eyes, and longer forelimb and first toe, besides larger SVL. Furthermore, F. sakishimensis has a larger body, and relatively shorter head, tibia and hindlimb than $F$. iskandari. Also, this species is differentiated from all other nominate taxa of the $F$. limnocharis complex by a combination of some morphological characteristics.
\end{abstract}

Key words: Cryptic species; Fejervarya limnocharis; Fejervarya sakishimensis; Ryukyu Archipelago; Yaeyama Islands

\section{INTRODUCTION}

An Asian ranid frog Fejervarya limnocharis (Gravenhorst, 1829) had long been placed in the genus Rana, and considered as one of the commonest anurans with an unusually wide geographic distribution, from Sri Lanka and India through Southeast Asia and continental

* Corresponding author. Tel: +81-75-753-6846;

Fax: +81-75-753-2891;

E-mail address: fumi@zoo.zool.kyoto-u.ac.jp
China and Taiwan to southwestern Honshu of Japan mainland (Boulenger, 1920; Kampen, 1923; Inger, 1947, 1966). Recent studies, however, revealed presence of quite a few distinct species under this name, and many new taxa have been described chiefly from South Asia (Dubois, 1975, 1984; Dutta, 1997). Dutta (1997) called these frogs as the Limnonectes limnocharis complex, but the complex was more recently moved to the resurrected genus Fejervarya Bolkay, 1915 (Dubois and Ohler, 2000). 
For Southeast and East Asian populations, taxonomic studies of this complex have been retarded in comparison with those for the South Asian members. However, studies on systematic aspects other than taxonomy have been intensively made in this region. For example, genetic studies through allozyme electrophoresis made by Nishioka and Sumida (1990) and Toda et al. (1997, 1998a, b) revealed the presence of substantial genetic differentiations among populations within Japan, and among Japanese, Taiwanese, Chinese and Southeast Asian populations of the F. limnocharis complex.

Most notable finding was the presence of two syntopic, but genetically distinct, populations in Java, Indonesia, which is the type locality of F. limnocharis (Toda et al., 1998a). Subsequently, Dubois and Ohler (2000) designated the neotype of $F$. limnocharis, and by comparison of this specimen with representative specimens of the two genetic groups in Java, Veith et al. (2001) described $F$. iskandari Veith, Kosuch, Ohler \& Dubois, 2001 from this island. This species, corresponding to "Malinping-B" of Toda et al. (1998a), is remote from the other genetically more uniform populations from Southeast Asia, with which the neotype of $F$. limnocharis was morphologically associated.

Besides these two Southeast Asian forms, Toda et al. (1998a) recognized at least two more distinct genetic groups in the $F$. limnocharis complex, one from China (Hongkong and Wenjiang) and the other from Ishigakijima Island of the Yaeyama Group, Ryukyu Archipelago, Japan. Nevertheless, the taxonomic status of these two East Asian groups remain uncertain.

Considering a large genetic distance (Nei's [1978] genetic distance [D'] $=0.287$ or 0.440 ) from $F$. limnocharis sensu stricto as defined above (corresponding to "Malinping-A" of Toda et al. [1998a]), each of these East Asian groups seems to be taxonomically distinct from $F$. limnocharis. However, it is not easy to classify the Chinese populations, because genetic differentiation between Hongkong and
Wenjiang populations was also not small (D'=0.250: Toda et al., 1998a). In designating the neotype of $F$. limnocharis, Dubois and Ohler (2000) also designated the neotype of F. multistriata (Hallowell, 1861) from Hongkong. Recent Chinese authors assign all Chinese populations of the $F$. limnocharis complex to this nominate species (Fei et al., 2002), but the situation is actually not so simple, because Dubois and Ohler (2000) merely assigned a neotype and gave a description of a single type specimen. Namely, status of $F$. multistriata as a good biological species has never been assessed.

By contrast, the Southern Ryukyu populations, as represented by Ishigakijima sample in Toda et al. (1998a), compose a more compact entity, and its distinct taxonomic status from F. limnocharis from Java is less complicated. It was Inger (1947) who reported that the population of Rana (now Fejervarya) limnocharis from the Ishigakijima Island differs morphologically from a population of Okinawa Island, Central Ryukyus. Subsequent studies confirmed and extended Inger's (1947) view by demonstrating great morphological, as well as acoustic, differences between the Southern Ryukyu and the other populations of Japan (i.e., populations from the Central Ryukyus and Japan Mainland) (Kuramoto, 1979; Maeda and Matsui, 1989). Extensive electrophoretic surveys further revealed great differentiation of the Southern Ryukyu populations from the other Japanese populations with substantial genetic distances (Nei's [1972] genetic distance $[D]=0.276-0.345$ in Nishioka and Sumida, 1990; D' $=0.523-0.733$ in Toda et al., 1997; and D or D' [not specified] $=0.310-0.404$ in Sumida et al., 2007). In contrast, the populations from Japan other than the Southern Ryukyus proved to be electrophoretically much closer to some Chinese populations $(\mathrm{D}=0.007-0.250$ : Toda et al., 1997), whose taxonomic assignment is not easy as noted above.

Setting the taxonomic problems of populations from the central Ryukyus, Japan Mainland and China aside, taxonomic position of 
the Southern Ryukyu populations can be determined by their direct comparisons with $F$. limnocharis from Java and other nominate species of the $F$. limnocharis complex. By comparing the Southern Ryukyu populations with topotypic specimens of $F$. limnocharis, $F$. multistriata, and $F$. iskandari, we have confirmed its morphological distinctness from all these species. Combined with known genetic uniqueness (see above), the Southern Ryukyu populations can be regarded as a distinct species of the F. limnocharis complex. Maeda and Matsui (1999) already considered these populations as specifically distinct and referred to them as Rana (Limnonectes) sp., but formal description of the Southern Ryukyu populations has never been made. The purpose of this study is to provide a description of these unnamed populations.

\section{MATERIALS AND METHODS}

We examined a total of 77 preserved specimens of the $F$. limnocharis complex from East and Southeast Asia stored at the Graduate School of Human and Environmental Studies, Kyoto University (KUHE), and Department of Zoology, Graduate School of Science, Kyoto University (KUZ): $F$. sp. from Ishigakijima Island $(\mathrm{n}=19)$ and Iriomotejima Island $(\mathrm{n}=19) ; F$. limnocharis from Malinping, Java $(\mathrm{n}=8) ; F$. iskandari from Malinping, Java $(\mathrm{n}=10) ; F$. multistriata from Hongkong $(n=9)$ and Guangzhou, southeastern China $(n=12)$. All these specimens but the $12 \mathrm{~F}$. multistriata from Guangzhou are those studied electrophoretically by Toda et al. (1998a). In order to assess morphometric differences among the samples, following 17 body measurements were taken to the nearest $0.1 \mathrm{~mm}$ with dial calipers, or with a stereoscopic binocular microscope, mainly after Matsui (1984): 1) snout-vent length (SVL); 2) head length (HL); 3) snout length (SL); 4) eye length (EL); 5) tympanum diameter (TD); 6) head width (HW); 7) internarial distance (IND); 8) interorbital distance (IOD); 9) upper eyelid width (UEW); 10) forelimb length
(FLL); 11) hindlimb length (HLL); 12) tibia length (TL); 13) foot length (FL); 14) inner metatarsal tubercle length (IMTL); 15) first toe length (1TL); 16) distance between anterior corners of eyes (AED); and 17) distance between posterior corners of eyes (PED). Data for some specimens of the $F$. limnocharis complex stored at the Museum National d'Histoire Naturelle, Paris (MNHNP), Natural History Museum, London (BM), Zoologisches Museum, Universität Humboldt, Berlin (ZMB), and Forschungsinstitut und Naturmuseum Senckenberg (SMF) were also incorporated. The system for description of toewebbing states is that used by Savage (1975).

Variation in adult SVL was examined by analysis-of-variance (ANOVA) with the Tukey range test. For the other characters, we converted each value to a percentage ratio to SVL for comparisons. We first confirmed the absence of significant difference in each of those characters between sexes in Ishigakijima and Iriomotejima samples of $F$. sp. (both entirely consisting of adults), and then combined data for both sexes for comparisons among these and other samples. For taxa other than the undescribed Southern Ryukyu species ( $F$. sp.), subadult specimens were also included to overcome small sample sizes following Veith et al. (2001), who adopted this procedure in the analysis of morphometric variation in the $F$. limnocharis complex from Southeast Asia. For ratio variables, KruskalWallis tests with nonparametric multiple comparisons or Mann-Whitney U tests were performed to detect the presence or absence of differences in the frequency distributions. The significance level was set at 0.05 .

\section{SYSTEMATICS}

Fejervarya sakishimensis sp. nov.

Fig. 1

Rana limnocharis: Stejneger, 1907, p. 129 (part); Okada, 1930, p. 127 (part); Okada, 1931, p. 138 (part); Inger, 1947, p. 334 (part); Okada, 1966, p. 112 (part); Utsunomiya, 1979, 


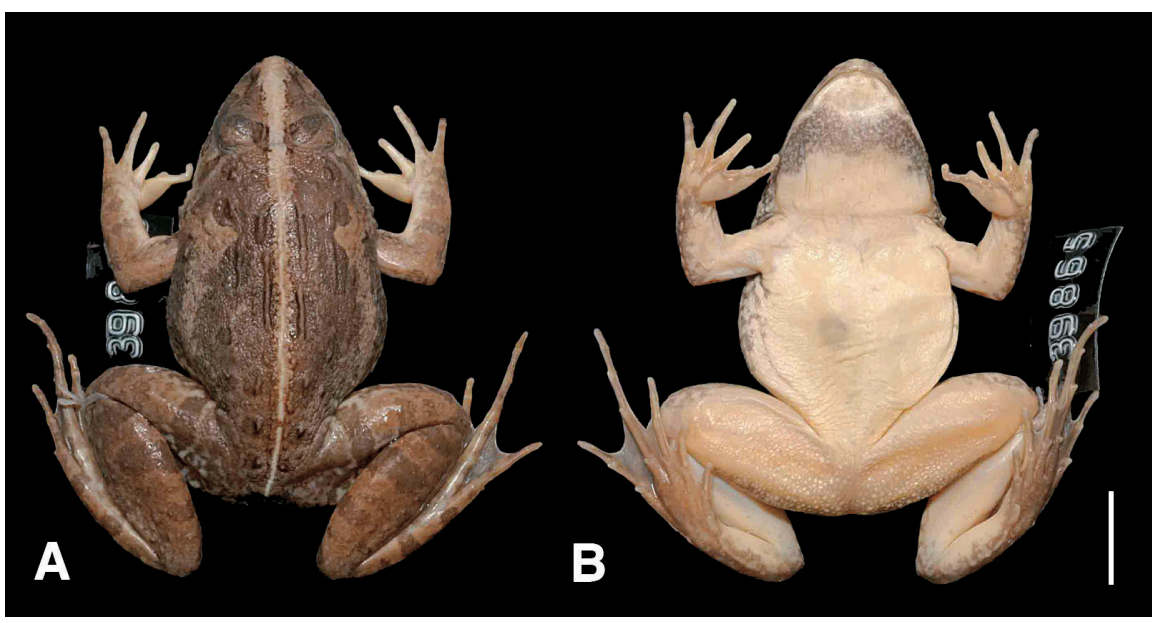

FIG. 1. Dorsal (A) and ventral (B) views of male holotype of Fejervarya sakishimensis sp. nov. (KUHE $39865, \mathrm{SVL}=50.3 \mathrm{~mm})$. Scale $b a r=10 \mathrm{~mm}$.

p. 154, fig.: Ota, 1981, p. 56, fig. 1; Toda et al., 1998b, p. 81 (part); Toda, 1999, p. 300 (part).

Rana limnocharis limnocharis: Kuramoto, 1973, p. 142; Toyama, 1976, p. 66, fig. 2; Ota, 1983, p. 15, fig. 1; Ikehara et al., 1984, p. 224, fig.

Rana limnocharis ssp.: Kuramoto, 1979, p. 10; Nishioka and Sumida, 1990, p. 151: Sumida et al., 2002, p. 303.

Rana (Euphlyctis) limnocharis ssp.: Maeda and Matsui, 1989, p. 110, figs. 2, 3, 6-8.

Rana sp.: Toda et al., 1997, p. 156; Toda et al., 1998a, p. 612.

Rana (Limnonectes) sp.: Maeda and Matsui, 1999, p. 114, figs. 1-12.

Fejervaria limnocharis: Watanabe et al., 2005, p. 87; Djong et al., 2007, p. 361 (part).

Fejervarya limnocharis ssp.: Sumida et al., 2007, p. 548, fig. 2.

\section{Diagnosis}

A large species of the $F$. limnocharis complex, with adult SVL (49-69 $\mathrm{mm}$ in females, $45-56 \mathrm{~mm}$ in males) larger than those in all nominate taxa from East and Southeast Asia with a ridge of skin on outer edge of fifth toe and low outer metatarsal tubercle. From $F$. limnocharis, this new species is differentiated by a larger ratio of the first toe length to the inner metatarsal tubercle, and smaller head, tibia, eye and internarial lengths, all relative to SVL. From $F$. multistriata, it differs by relatively larger tympanum, wider head, upper eyelid, anterior and posterior spaces of eyes, and longer forelimb and first toe. It has relatively shorter head, tibia, and hindlimb than $F$. iskandari.

\section{Holotype}

KUHE 39865, an adult male from Omoto $\left(124^{\circ} 11^{\prime} \mathrm{E}, 24^{\circ} 22^{\prime} \mathrm{N}\right.$, alt. $\left.60 \mathrm{~m}\right)$ in Ishigaki-shi, Okinawa Prefecture (Ishigakijima Island of the Yaeyama Group, Southern Ryukyus), Japan. Collected on 24 August 1998, by Masataka Matsui.

\section{Paratypes}

All from Ishigakijima Island. KUHE 39730 39746 collected from Banna Park on 19 May 1999, by S.-L. Chen, Y. Hokama, and K. Takahashi; KUHE 39866-39868 same data as the holotype; KUHE 39869-39888 collected from Mt. Omoto-dake on 26 May 1999, by S. L. Chen, Y. Hokama, and K. Takahashi.

\section{Referred specimens}

Ishigakijima Island: KUZ 8 from Yonehara on 11 March 1981 by H. Ota; KUZ 401 from Ishigaki Airport on 6 March 1982 by H. Ota; KUZ 909, 910 from Yonehara on 12 March 
1983 by H. Ota. Iriomotejima Island: KUZ 49, 50 from Toyohara on 18 March 1981 by $\mathrm{H}$. Ota; KUZ 89, 90 from Funaura on 25 March 1981 by H. Ota; KUZ 485, 486 from Toyohara on 14 May 1982 by H. Ota; KUZ 499 from Komi on 14 March 1982 by H. Ota; KUZ 506, 515, 516 from Komi-Ohara on 15 March 1982 by H. Ota; KUZ 4623-4627 from Sonai on 27 March 1983 by H. Ota; KUZ 4651-4660 on 27 March 1983 by H. Ota; KUHE 5983 from Komi on 16 March 1980 by M. Hinoue; KUHE 5984 from Otomi on 13 March 1980 by M. Hinoue; KUHE 6174-6176 from Kampirei on 13 July 1980 by M. Hinoue. Kohamajima Island: KUZ 337 on 23 August 1981 by H. Ota; KUHE 7471-7473 on 11 March 1984 by H. Ota. Yonagunijima Island: KUZ 405-410 from Higawa on 6-7 March 1982 by $\mathrm{H}$. Ota; KUZ 418 from Sonai on 8 March 1982 by H. Ota; KUZ 445-450, 452 from Higawa on 9 March 1982 by H. Ota; KUZ 2859, 2860 from Higawa on 21 March 1983 by $\mathrm{H}$. Ota; KUZ 4665-4667 from Higawa on 22 March 1983 by H. Ota: KUZ 4669, 4671-4673, 4675-4681 from Kubura on 18 March 1983 by H. Ota; KUHE 7481-7483 from Mt. Urabu-dake on 15 March 1984 by H. Ota. Haterumajima Island: KUZ 469 on 11 March 1982 by H. Ota; KUZ 4661 on 15 March 1983 by H. Ota. Kuroshima Island: KUHE 7480 on 13 March 1984 by H. Ota. Miyakojima Island: KUZ 4628 from Hirara Botanical Garden on 24 March 1983 by $\mathrm{H}$. Ota.

\section{Description of holotype (measurements in $\mathrm{mm}$ )}

Body moderately stocky, SVL 50.3; head triangular, longer (19.8) than wide (18.3); snout dorsally rounded, projecting beyond lower jaw, sloping in profile; eye moderate, length (7.4) shorter than snout (8.2); canthus indistinct; lores concave, sloping; nostril below canthus, slightly closer to tip of snout (4.4) than to eye (4.0); internarial distance (3.2) wider than interorbital distance (2.6); latter much narrower than upper eyelid (4.8); distance between anterior tips of eyes (7.7) more than half of distance between posterior tips of eyes (11.6); pineal spot visible, posterior to line connecting anterior corners of orbits; tympanum (3.5) conspicuous, three-sevenths of eye diameter and separated from eye by more than one-third of tympanic diameter (1.4); vomerine teeth in short, oblique groups (four and five teeth), beginning from a line connecting anterior borders of choanae and extending posteromedially, groups more narrowly separated from each other than from choanae; tongue deeply notched, without papillae; median external subgular vocal sacs; vocal openings slit-like, on each side of mouth.

Forelimb (29.2) moderately stout; fingers thin, unwebbed; the second finger with very narrow fringes of skin; relative length of fingers, shortest to longest: IV $<$ II $<$ I $<$ III; tips not expanded; subarticular tubercles prominent, rounded, single; prepollex oval, prominent; two oval, distinct palmar tubercles; supernumerary tubercles absent.

Hindlimb heavy and rather short (79.6), about 2.7 times the length of forelimb; tibia (23.7) shorter than foot (25.2); heels slightly overlapping when limbs are held at right angles to body; tibiotarsal articulation of adpressed limb reaching center of eye; toes long, relative length shortest to longest: I $<$ II $<$ IV $<$ III $<$ V; tips not expanded; toes moderately webbed, webbing formula: I1-2II1$2^{1} /{ }_{2} \mathrm{III} 1^{1} /{ }_{2}$-3IV3- $1 \frac{1}{2} \mathrm{~V}$; subarticular tubercles very prominent, oval; a ridge of skin on outer edge of fifth toe, from tip of toe to base of metatarsus; inner metatarsal tubercle distinct, oval, length (2.3) two-fifths of first toe length (5.7); outer metatarsal tubercle low and round; an inner tarsal ridge along distal half of tarsus.

Dorsum with irregular skin folds, with pustular warts and granules in between; no dorsolateral fold; a supratympanic fold from eye to axilla; side of trunk coarsely granular; ventral side smooth with minute colorless asperities except on posterior half of throat; distinct nuptial pads, gray in color and velvety in structure, covering dorsal and median surfaces of the first finger from its base to the level of subarticular tubercle; skin on throat side modified; a ventrolateral 
fold from axilla to groin, and a sinuous fold across breast.

\section{Color in alcohol}

Dorsum grayish brown with large dark blotches including interorbital bar; a light vertebral band with a narrow white line medially; lores with dark markings below canthus; upper lip with dark bars; upper half of tympanum surrounded by a brown band; limbs marked dorsally with wide and incomplete, dark brown crossbars; rear of thigh with irregular dark reticulations; ventrum white with black M-shaped bands across throat; lower lip barred with blackish brown; ventral surfaces of thigh and tibia whitish.

\section{Variation}

In both Ishigakijima and Iriomotejima populations, females were significantly larger than males in SVL (ANOVA, $\mathrm{P}<0.05$ ), whereas no significant differences were recognized in this character between males or females from the two islands (ANOVA, P>0.05: Table 1). Statistical comparisons within Ishigakijima population revealed no sexual dimorphisms in all other characters in ratios (Mann-Whitney U tests, $\mathrm{P}>0.05$ ). Ishigakijima and Iriomotejima populations did not differ in body proportions in either sex. The point reached by the tibiotarsal joint of the hindlimb, bent forward along the body, varied from the anterior corner of tympanum to between the anterior corner of eye and nostril, but mostly lies at the center of eye in both sexes. Degree of development of toe webbing did not differ sexually. Females lacked black M-shaped bands across throat, nuptial pads on the first finger, and colorless asperities on ventrum.

Dorsal ground color in life varied from light

TABLE 1. Morphological variation in adult Fejervarya sakishimensis from two islands of the Yaeyama Group, Southern Ryukyus. SVL ( $\overline{\mathrm{x}} \pm 1 \mathrm{SD}$ ), medians of ratios of other characters to SVL, and medians of two sets of characters, followed by ranges in parentheses. See text for character abbreviations.

\begin{tabular}{lrccccccc}
\hline \multirow{2}{*}{ Sex (n) } & \multicolumn{3}{c}{ Ishigakijima Island } & \multicolumn{5}{c}{ Iriomotejima Island } \\
\cline { 2 - 9 } & \multicolumn{3}{c}{ Male (12) } & \multicolumn{2}{c}{ Female (7) } & \multicolumn{2}{c}{ Male (10) } & \multicolumn{1}{c}{ Female (9) } \\
\hline SVL & $51.7 \pm 3.1$ & $(46.0-55.5)$ & $61.3 \pm 3.8$ & $(54.8-66.0)$ & $51.7 \pm 2.9$ & $(45.2-55.5)$ & $59.9 \pm 6.9$ & $(48.5-69.2)$ \\
RHL & 37.4 & $(36.5-39.4)$ & 37.3 & $(33.8-39.5)$ & 38.2 & $(36.3-40.1)$ & 37.5 & $(35.5-38.8)$ \\
RSL & 16.3 & $(15.5-17.2)$ & 16.4 & $(15.0-16.7)$ & 17.2 & $(16.2-18.5)$ & 16.7 & $(15.9-18.9)$ \\
REL & 14.0 & $(13.4-15.0)$ & 13.6 & $(12.5-13.8)$ & 12.8 & $(11.9-13.5)$ & 12.0 & $(11.1-14.4)$ \\
RTD & 7.4 & $(6.6-9.9)$ & 7.0 & $(6.3-7.6)$ & 7.8 & $(6.3-8.6)$ & 7.0 & $(6.3-8.2)$ \\
RHW & 36.9 & $(35.9-38.6)$ & 35.7 & $(35.0-37.4)$ & 36.9 & $(35.1-38.3)$ & 36.3 & $(34.2-38.2)$ \\
RIND & 6.8 & $(6.4-7.5)$ & 6.8 & $(6.4-7.4)$ & 7.0 & $(6.3-7.7)$ & 6.9 & $(6.3-7.4)$ \\
RIOD & 5.2 & $(4.8-6.1)$ & 5.7 & $(4.7-6.0)$ & 5.6 & $(4.6-6.5)$ & 4.8 & $(3.2-6.3)$ \\
RUEW & 9.3 & $(9.0-10.3)$ & 9.3 & $(8.3-9.4)$ & 9.9 & $(8.8-10.8)$ & 9.5 & $(8.4-10.7)$ \\
RFLL & 59.1 & $(55.5-61.4)$ & 56.8 & $(55.3-57.3)$ & 59.8 & $(56.3-61.5)$ & 56.5 & $(54.2-62.0)$ \\
RHLL & 161.8 & $(148.9-174.6)$ & 161.3 & $(147.4-166.4)$ & 167.2 & $(153.7-175.3)$ & 161.2 & $(151.7-168.9)$ \\
RTL & 48.3 & $(45.2-52.0)$ & 48.9 & $(46.7-51.2)$ & 50.6 & $(46.9-52.4)$ & 48.8 & $(46.8-50.4)$ \\
RFL & 53.1 & $(50.1-59.6)$ & 53.2 & $(51.7-57.3)$ & 55.3 & $(53.1-60.7)$ & 53.8 & $(49.6-56.7)$ \\
RIMTL & 5.0 & $(4.1-6.1)$ & 5.7 & $(4.8-6.2)$ & 5.3 & $(4.9-6.5)$ & 5.4 & $(4.8-6.4)$ \\
R1TL & 12.3 & $(10.8-14.1)$ & 12.7 & $(12.0-13.1)$ & 12.4 & $(11.5-14.4)$ & 12.6 & $(11.8-14.8)$ \\
RAED & 15.4 & $(14.3-16.8)$ & 15.1 & $(11.8-16.0)$ & 15.7 & $(14.3-17.4)$ & 14.6 & $(12.4-15.9)$ \\
RPED & 23.3 & $(22.2-25.2)$ & 23.0 & $(17.6-24.2)$ & 23.4 & $(22.3-24.9)$ & 21.7 & $(19.8-24.5)$ \\
PED/AED & 1.50 & $(1.39-1.71)$ & 1.46 & $(1.36-1.52)$ & 1.51 & $(1.41-1.57)$ & 1.50 & $(1.40-1.59)$ \\
1TL/IMTL & 2.35 & $(2.04-2.76)$ & 2.24 & $(2.03-2.58)$ & 2.28 & $(1.88-2.84)$ & 2.41 & $(1.97-2.62)$ \\
\hline
\end{tabular}


brown to dark greenish brown. The light vertebral band showed three character states, (1) absent, (2) present as a narrow line, and (3) present as a broad stripe, and their frequencies did not differ sexually. In 40 specimens from Ishigakijima Island and Iriomotejima Island, frequencies of the character states (1), (2), and (3) were $57.5 \%, 35.0 \%$, and $7.5 \%$, respectively. These values slightly differ from those reported for a population of Miyakojima Island of the Miyako Group (55.7\%, 21.7\%, and $22.6 \%$, respectively, in 106 specimens: Toyama, 1976) or for Haterumajima population $(55.2 \%, 24.1 \%$, and $20.7 \%$, respectively, in 29 specimens: Ota, 1981).

\section{Calls}

Calls were recorded by $\mathrm{H}$. Ota on Ishigakijima Island at an air temperature of $23 \mathrm{C}$. This species basically had two types of calls, i.e., short and long calls, with the latter being not always emitted. The short call consisted of a series of pulsed notes. Each of these pulse notes lasted 250 millisecond (msec) and was composed of 4-7 pulses. The note gap ranged 100-200 msec. The dominant frequency lied at approximately $1030 \mathrm{~Hz}$, and the second harmonic was at $2120 \mathrm{~Hz}$. The call had a slight frequency modulation.

\section{Eggs and larvae}

The clutch size ranges from 3300 to 3800 and the ovum diameter from 1.2 to $1.4 \mathrm{~mm}$. The animal hemisphere of egg is light brown in color. Matured larva is about $32 \mathrm{~mm}$ in total length with a low tail fin and the dental formula of 2(2)/3(1-2). The SVL at metamorphosis is about $13 \mathrm{~mm}$ (Maeda and Matsui, 1999).

\section{Karyotype}

Diploid chromosome number is 26 , with five large and eight small pairs. Chromosomes forming pairs 4,8 , and 11 are submetacentric and the remaining ten pairs are metacentric. Secondary constrictions are recognized on the shorter arms of pair 7 (Maeda and Matsui, 1999).

\section{Comparisons}

Fejervarya sakishimensis differs from topotypic sample of $F$. limnocharis in larger adult SVL (45.2-55.5 $\mathrm{mm}$ in males and 48.5$69.2 \mathrm{~mm}$ in females vs $34.9-37.7 \mathrm{~mm}$ in males and 42.9-47.9 $\mathrm{mm}$ in females: Table 2). When both sexes of adults and subadults are combined, F. sakishimensis has shorter head and tibia, smaller eye, and narrower internarial, all relative to SVL, than topotypic $F$. limnocharis. In contrast, the ratio of the first toe length to the inner metatarsal tubercle is larger in $F$. sakishimensis (Kruskal-Wallis tests with multiple comparisons, $\mathrm{P}<0.05$ : Table 2). From $F$. multistriata, F. sakishimensis differs by relatively larger tympanum, wider head, upper eyelid, anterior and posterior spaces of eyes, and longer forelimb and first toe, besides larger SVL (32.8 mm: Matsui's observation of male neotype of $F$. multistriata in ZMB; 40.4 $44.4 \mathrm{~mm}$ in males and $44.6-52.4 \mathrm{~mm}$ in females of other specimens examined by us: Table 2). Furthermore, compared with $F$. iskandari, F. sakishimensis has larger body $(\mathrm{SVL}=35.6-39.0 \mathrm{~mm}$ in males and 39.4$45.2 \mathrm{~mm}$ in females of $F$. iskandari), and relatively shorter head, tibia, and hindlimb (Table 2).

The following species are smaller in SVL than F. sakishimensis: F. brevipalmata (Peters, 1871) from India (21.2-47.0 mm: Dutta [1997] as Limnonectes), F. kirtisinghei (Manamendra-Arachchi and Gabadage, 1996) from Sri Lanka (25.9-40.8 mm: Dutta [1997] as Limnonectes), F. syhadrensis (Annandale, 1919) from India, Pakistan, and Nepal (27.0-31.5 mm in males and 29.5-40.0 mm in females: Dubois [1975] as Rana), F. nepalensis (Dubois, 1975) from Nepal (27.0-31.5 mm in males and 31.5$40.0 \mathrm{~mm}$ in females: Dubois [1975] as Rana), F. keralensis (Dubois, 1981) from India and Nepal (28.3-59.8 mm: Dutta [1997] as Limnonectes), F. sauriceps (Rao, 1937) from India (30.0 mm: Dutta [1997] as Limnonectes), F. pierrei (Dubois, 1975) from Nepal (30.0-34.5 mm in males and $34.0-46.0 \mathrm{~mm}$ in females: Dubois [1975] as Rana), F. orissaensis (Dutta, 1997) from India (36.2-47.2 $\mathrm{mm}$ in 
TABLE 2. Morphometric comparison of Fejervarya sakishimensis from two islands of the Yaeyama Group, Southern Ryukyus (total $\mathrm{n}=38$, including 22 adult males and 16 adult females) with $F$. limnocharis (total $\mathrm{n}=8$, including three adult males and two adult females), $F$. multistriata (total $\mathrm{n}=21$, including four adult males and 13 adult females), and $F$. iskandari (total $\mathrm{n}=10$, including two adult males and four adult females). SVL ( $\overline{\mathrm{x}} \pm 1 \mathrm{SD}$, in $\mathrm{mm}$ ) and medians of ratios (R) of other characters to SVL, followed by ranges in parentheses. * significant difference $(\mathrm{p}<0.05)$ from $F$. sakishimensis.

\begin{tabular}{lcccccccc}
\hline \multicolumn{2}{c}{ F. sakishimensis } & \multicolumn{2}{c}{ F. limnocharis } & \multicolumn{2}{c}{ F. multistriata } & \multicolumn{2}{c}{ F. iskandari } \\
\hline Male SVL & $51.7 \pm 3.0$ & $(45.2-55.5)$ & $36.8 \pm 1.6^{*}$ & $(34.9-37.7)$ & $42.3 \pm 2.0^{*}$ & $(40.4-44.4)$ & $37.3^{*}$ & $(35.6-39.0)$ \\
Female SVL & $60.6 \pm 5.6$ & $(48.5-69.2)$ & $45.4^{*}$ & $(42.9-47.9)$ & $47.2 \pm 2.9^{*}$ & $(44.6-52.4)$ & $42.6 \pm 2.5^{*}$ & $(39.4-45.2)$ \\
RHL & 37.5 & $(33.8-40.1)$ & $40.1^{*}$ & $(37.7-43.4)$ & 37.9 & $(34.9-42.2)$ & $39.0^{*}$ & $(37.4-40.4)$ \\
RSL & 16.6 & $(15.0-18.9)$ & 16.6 & $(15.9-18.1)$ & 16.2 & $(13.8-17.8)$ & 16.6 & $(15.1-17.7)$ \\
REL & 13.3 & $(11.1-15.0)$ & $14.5^{*}$ & $(13.6-15.5)$ & 12.6 & $(10.5-14.1)$ & 14.0 & $(12.9-15.2)$ \\
RTD & 7.4 & $(6.3-9.9)$ & 7.4 & $(6.7-8.2)$ & $6.9^{*}$ & $(5.5-7.5)$ & 7.2 & $(6.2-8.6)$ \\
RHW & 36.8 & $(34.2-38.6)$ & 37.2 & $(33.7-42.3)$ & $35.0^{*}$ & $(32.4-38.6)$ & 37.1 & $(35.2-38.7)$ \\
RIND & 6.9 & $(6.2-7.7)$ & $7.7^{*}$ & $(7.0-9.3)$ & 6.9 & $(5.7-7.8)$ & 7.1 & $(6.5-7.7)$ \\
RIOD & 5.5 & $(3.2-6.9)$ & 5.6 & $(4.7-6.4)$ & 5.7 & $(4.3-6.5)$ & 5.6 & $(4.4-6.2)$ \\
RUEW & 9.5 & $(8.3-11.0)$ & 9.0 & $(8.2-10.3)$ & $8.8^{*}$ & $(7.8-9.8)$ & 9.4 & $(7.9-10.7)$ \\
RFLL & 58.4 & $(54.2-64.0)$ & 56.0 & $(52.4-60.6)$ & $54.9^{*}$ & $(50.6-58.2)$ & 57.2 & $(51.4-61.8)$ \\
RHLL & 161.8 & $(147.4-175.3)$ & 173.5 & $(158.9-189.5)$ & 161.6 & $(135.4-176.2)$ & $173.5^{*}$ & $(155.3-192.9)$ \\
RTL & 49.0 & $(45.2-52.4)$ & $52.6^{*}$ & $(47.7-58.3)$ & 50.3 & $(41.1-56.1)$ & $53.0^{*}$ & $(47.2-56.4)$ \\
RFL & 54.0 & $(49.6-60.7)$ & 54.5 & $(49.1-61.8)$ & 53.0 & $(43.9-58.9)$ & 57.2 & $(50.0-61.6)$ \\
RIMTL & 5.3 & $(4.1-6.5)$ & 5.7 & $(5.1-6.6)$ & 5.4 & $(4.3-6.5)$ & 5.3 & $(4.8-5.8)$ \\
R1TL & 12.5 & $(10.8-14.8)$ & 11.3 & $(10.9-13.4)$ & $11.3^{*}$ & $(9.2-13.9)$ & 12.2 & $(11.5-14.0)$ \\
RAED & 15.4 & $(11.8-17.4)$ & 15.3 & $(13.8-16.3)$ & $14.0^{*}$ & $(11.7-16.2)$ & 14.9 & $(13.1-17.7)$ \\
RPED & 23.0 & $(17.6-25.2)$ & 23.3 & $(20.7-24.5)$ & $21.4^{*}$ & $(19.7-22.3)$ & 23.8 & $(21.1-25.1)$ \\
\hline
\end{tabular}

males and $34.2-53.8 \mathrm{~mm}$ in females: Dutta [1997] as Limnonectes), F. murthii (Pillai, 1979) from India (35.0 mm: Dutta [1997] as Limnonectes), F. greenii (Boulenger, 1905) from Sri Lanka (37.4-48.9 mm: Matsui's observation of syntypes in $\mathrm{BM})$, and $F$. mysorensis (Rao, 1922) from India $(37.0 \mathrm{~mm}$ : Dutta [1997] as Limnonectes).

Fejervarya nilagirica (Jerdon, 1854) from India is smaller (SVL $=34.7-42.2 \mathrm{~mm}$ in males and $44.5-49.6 \mathrm{~mm}$ in females) than $F$. sakishimensis and lacks dermal fringe along the fifth toe (Matsui's observation of specimens in MNHP). Fejervarya triora Stuart, Chuaynkern, Chan-ard, \& Inger, 2006 from Thailand is similar to $F$. sakishimensis in size (54.9$60.2 \mathrm{~mm}$ in females), but has broader head and supratympanic fold with large oval warts on dorsum, in contrast to the long narrow fold in F. sakishimensis. Fejervarya teraiensis
(Dubois, 1984) from Nepal is also similar to $F$. sakishimensis in size $(40.1-50.5 \mathrm{~mm}$ in males and 51.6-61.2 $\mathrm{mm}$ in a part of type series), but has shorter hindlimb, with the tibiotarsal joint reaching usually to center of tympanum, and at most to posterior corner of eye (Matsui's observation of the type series in MNHP). Fejervarya vittigera (Wiegmann, 1834) from the Philippines overlaps $F$. sakishimensis in size $(37.3-66.6 \mathrm{~mm}$ in males and $38.8-$ $80.6 \mathrm{~mm}$ in females: Inger [1954] as Rana), but lacks a flap of skin on outer edge of fifth toe and outer metatarsal tubercle, unlike $F$. sakishimensis. Fejervarya cancrivora (Gravenhorst, 1829) from China through Vietnam, Malaysia to Thailand, and through Borneo to the Philippines and the Lesser Sundas, and $F$. raja (Smith, 1930) from Thailand to Malaysia have toe webbing much more developed than in F. sakishimensis. Fejervarya verruculosa 
(Roux, 1911) from Indonesia and Papua New Guinea lacks outer metatarsal tubercle, has nearly entire webbing (Kampen, 1923), and characteristically possesses large white blotches on flank and at the base of thigh (Matsui's observation of the holotype in SMF).

Fejervarya altilabris (Blyth, 1856) from Myanmar, F. assimilis (Blyth, 1852), F. brama (Lesson, 1834) and F. sauriceps (Rao, 1937) from India, $F$. frithii (Theobald, 1868) from Bangladesh, and F. moodiei (Taylor, 1920) from Philippines seem to be invalid. Fejervarya parambikulamana (Rao, 1937) and $F$. rufescens (Jerdon, 1854) from India seem to be members of Tomopterna, and $F$. pulla (Stoliczka, 1870) from Malaysia and $F$. schlueteri (Werner, 1893) from Borneo may be Hoplobatrachus. Exact taxonomic status of $F$. andamanensis (Stoliczka, 1870) from the Andaman and Nicobar Islands, India, is unclear, and synonymizing it with Rana (Sylvirana) nicobariensis (Stoliczka, 1870), a species recorded from a broad area from the Philippines through Java, Sumatra and Borneo to the Nicobar Islands and Thailand (Dubois, 1984) and placing the latter in Fejervarya (Dubois and Ohler, 2000) are dubious.

\section{$D N A$}

In 636 base pairs of the cytochrome b gene of mitochondrial DNA (mtDNA), genetic distances calculated by Kimura's (1980) twoparameter method was $0-0.8 \%$ between Ishigakijima and Iriomotejima populations of $F$. sakishimensis. The divergences of $F$. sakishimensis from populations of the $F$. limnocharis complex from some neighboring regions were much greater: $9.6-9.7 \%$ from the Japan mainland populations, 11.4-11.6\% from Okinawajima population, $11.8-12.2 \%$ from Chinese populations, and 10.3-10.6\% from Thailand populations (Matsui et al., unpublished data).

\section{Range}

Known from most islands of the Southern Ryukyus (Toyama, 1976, 1981; Ota, 1981, 1983; Ikehara et al., 1984; Nohina et al., 1998;

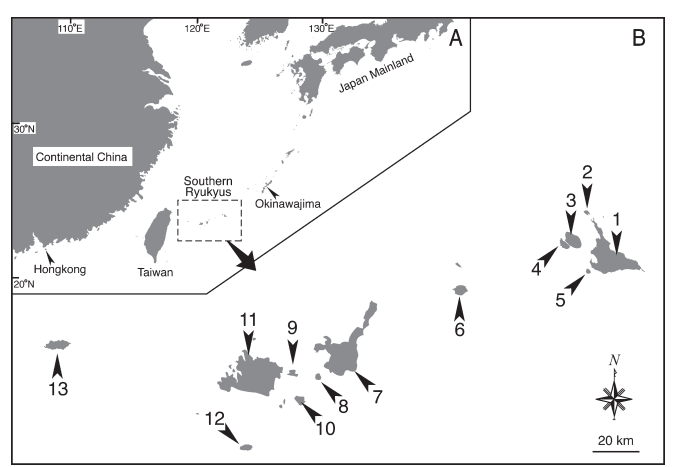

FIG. 2. Maps of East Asia (A) and details of the Southern Ryukyus (B). Arrowheads indicate islands, on which Fejervarya sakishimensis sp. nov. occurs. 1=Miyakojima Island, 2=Ikemajima Island, 3=Irabujima Island, 4=Shimojijima Island, 5= Kurimajima Island, 6=Taramajima Island, $7=$ Ishigakijima Island, $8=$ Taketomijima Island, $9=$ Kohamajima Island, $10=$ Kuroshima Island, $11=$ Iriomotejima Island, 12=Haterumajima Island, $13=$ Yonagunijima Island.

Ota et al., 2004: Fig. 2)—Miyakojima Island, Ikemajima Island, Irabujima Island, Shimojijima Island, Kurimajima Island and Taramajima Island of the Miyako Group, and Ishigakijima Island, Iriomotejima Island, Kohamajima Island, Taketomijima Island, Kuroshima Island, Haterumajima Island and Yonagunijima Island of the Yaeyama Group. Populations on Taramajima, Kuroshima and Yonagunijima Islands were artificially introduced. Feral populations originating from artificial introductions are known also from Kitadaitojima and Minamidaitojima Islands of the Daito Group.

\section{Natural history}

This species chiefly occurs around marshes, ditches, rice paddies, and grasslands with temporary fresh-water pools on plains (Kuramoto, 1973; Ota, 1981, 1983, unpublished observations). On Ishigakijima and Iriomotejima, however, the species also occurs in montane regions, and is often found in high density on forest floors (Watanabe et al., 2005). The breeding season is from April to August, and eggs are laid in various types of 
still waters, including rice fields, ponds, and rain pools. Egg masses are attached to weeds in a small clump or larger mass. Metamorphosis takes place from May to August (Maeda and Matsui, 1999). Anuran species inhabiting in association with $F$. sakishimensis include Bufo gargarizans miyakonis Okada, 1931, Rana (Odorrana) supranarina Matsui, 1994, R. (O.) utsunomiyaorum Matsui, 1994, R. (Nidirana) okinavana Boettger, 1895, Rhacophorus owstoni (Stejneger, 1907), Buergeria japonica (Hallowell, 1861) and Microhyla okinavensis Stejneger, 1901 (Kuramoto, 1973; Toyama, 1976, 1981; Ota, 1981, 1983; H. Ota, unpublished observations). Known predators of $F$. sakishimensis include snakes (Amphiesma concelarum Malnate, 1963, A. ishigakiense [Malnate and Munsterman, 1960], Dinodon rufozonatum walli Stejneger, 1907, and Protobothrops elegans [Gray, 1849]), one scincid lizard (Plestiodon kishinouyei [Stejneger, 1901]), two predatory birds (Spilornis cheela perplexus Swann, 1922 and Corvus macrorhynchos Wagler, 1827), and one carnivorous mammal (Prionailurus iriomotensis [Imaizumi, 1967]) (Mori and Moriguchi, 1988; Sano, 2003; Watanabe and Izawa, 2005; H. Ota, unpublished observations).

\section{Etymology}

The specific name is derived from "Sakishima", an old vernacular name referring to the Southern Ryukyus, where this species occurs.

\section{DISCUSSION}

By employing the methods other than the conventional morphological one, several Oriental anurans of different lineages, once considered as single widely ranging species, have proved to include cryptic sympatric and allopatric species (Matsui et al., 2005; Stuart et al., 2006). This holds for the Fejervarya limnocharis complex, which has been shown to include some morphologically similar but reproductively isolated entities (Toda et al., 1998a; Veith et al., 2001; Djong et al., 2007;
Sumida et al., 2007). Toda et al. (1998a) electrophoretically recognized at least four distinct lineages in the Southeast and East Asian $F$. limnocharis complex, one of which corresponds to the present new species from the Southern Ryukyus. In an earlier study, Stejneger (1907) examined 20 Ishigakijima specimens of the $F$. limnocharis complex $(=F$. sakishimensis $)$, and noted the presence of a narrow vertebral line in all of them. He, however, did not mention of other characters in these specimens, such as the body size. Okada $(1930,1931)$ listed East Asian specimens of the $F$. limnocharis complex in the tables of measurements, which clearly showed a distinctly large body size of the Southern Ryukyu specimens. However, he did not give any remarks on this feature.

It was Inger (1947) who first noted unique morphology of the Southern Ryukyu populations. He examined those Ishigakijima specimens that had been examined by Stejneger (1907) and found their large body size and relatively long hindlimb compared with specimens from Okinawajima Island. Inger (1947) also noted the presence in the Ishigakijima, but absence in the Okinawajima specimens of a vertebral line, and pointed out the similarity of the former to specimens from Southeast Asia. He suggested the possibility of recognizing at least two subspecies in F. (as Rana) limnocharis, one in western China and the other from Southeast Asia, including Taiwan and the Southern Ryukyus. He, however, refrained from further discussion on the taxonomic status of the Okinawajima population because of the lack of more northern specimens (see below).

In a more recent monographic work of the Japanese amphibians and reptiles, neither Nakamura and Uéno (1963) nor Okada (1966) gave remarks on characteristic features of the Southern Ryukyu populations. Kuramoto (1967, 1968, 1971) intensively studied $F$. (as Rana) limnocharis, but his material did not include the Southern Ryukyu representatives. He (Kuramoto, 1973) studied the population from Iriomotejima Island and noted that half of the 
specimens examined had a vertebral line as reported by previous authors for the Ishigakijima population. Toyama (1976) reported morphological variations in the Miyako populations and noted them to be similar to the Ishigakijima population rather than to the Okinawajima population. Ota (1981) also reported morphological variations in the Haterumajima population, and noted its similarity to the Miyako populations in the frequent occurrence of the vertebral line.

Kuramoto (1979) reviewed F. (as Rana) limnocharis from the Ryukyus and suggested that the Southern Ryukyu populations could be split at the subspecies level from Okinawajima and more northern populations of Japan and Taiwanese populations by their large body size, less fidelity to the riparian habitats, and longer inter-pulse and inter-call intervals and lower frequency of calls. Maeda and Matsui (1989) supported this view to differentiate the Southern Ryukyu populations as a distinct subspecies of $F$. (as Rana) limnocharis. Subsequently, Nishioka and Sumida (1990), and Toda et al. (1997) made electrophoretic analyses of allozymes. Both of these analyses revealed a remarkable genetic divergence of those populations from populations of other regions of Japan, Taiwan, and China (see above).

Maeda and Matsui (1999), thus, concluded to differentiate the Southern Ryukyu populations from the other populations of $F$. (as Rana) limnocharis at the specific rank, but did not name it. In contrast, Sumida et al. (2002) considered the former as a subspecies of $F$. (as Rana) limnocharis chiefly from the pattern of sequence variations in mtDNA and the result of crossing experiments. These authors constructed an $\mathrm{NJ}$ tree from sequences of $12 \mathrm{~S}$ and 16S rRNA genes of mtDNA, in which three major clusters, each consisting of Japan mainland sample, Southern Ryukyus sample, and Okinawajima and Taiwanese samples, were recognized. Based on the artificial hybridization experiment, Sumida et al. (2002) also provided data that were interpreted as indicating nearly free production of
F1 hybrids between populations from the Southern Ryukyus and Japan mainland. Furthermore, these authors argued that both males and females obtained through backcross of the F1 hybrids were almost normal in reproductive capacity, in terms of the ratios of normally cleaved eggs, hatched larvae, feeding tadpoles, and metamorphosed young. Based on these data, Sumida et al. (2002) concluded that there is no reproductively isolating mechanism among the Japanese populations of $F$. (as Rana) limnocharis, and that the Southern Ryukyu populations are most appropriately placed as a subspecies of $F$. (as Rana) limnocharis. This view clearly supports Kuramoto's (1979) proposal (see above). However, data and photographs provided in Sumida et al. (2002) show that the percentage of hybrid males between the Southern Ryukyu and Japan mainland samples considerably fluctuated depending on the combinations of parents, and that numerous pycnotic nuclei were actually observed in the seminiferous tubules of the testes of males from hybridization between Iriomotejima and Honshu (Hiroshima and Nagoya) samples. Furthermore, the sex ratio in individuals from the back cross experiment also greatly fluctuated depending on the combinations between female and male parents.

In spite of their own conclusion of reproductive isolation, Sumida et al.'s (2002) taxonomic idea clearly indicates that they admitted presence of a large degree of genetic differentiation between the Southern Ryukyu and the other Japanese populations of the $F$. (as Rana) limnocharis complex. Maeda and Matsui's (1999) taxonomic decision is based on unique genetic differentiation in terms of allozyme variation (Toda et al., 1997) and possible premating isolating mechanism in the field as predicted by the differences in mating calls (see above). Genetic distances estimated from allozyme electrophoresis between $F$. sakishimensis and adjacent populations differ even using same protocols (compare Djong et al. [2007] and Sumida et al. [2007]), but results of most studies made by now indicate substantial differentiation between them (Nei's 
$\mathrm{D}=0.28-0.39$ in Nishioka and Sumida [1990], $0.36-0.73$ in Toda et al. [1997], 0.26-0.46 in Toda et al. [1998b], and 0.31-0.40 in Sumida et al. [2007]). We don't rely on the genetic distance as an absolute standard for determining taxonomic relationships, but genetic distances above 0.3 is often considered as indicating heterospecific relationships among amphibian populations (see discussion in Djong et al. [2007]).

Similarly important issue to be discussed is the taxonomic status of populations from Japan mainland, Okinawajima and adjacent islands, and Taiwan, that have been simply assigned to $F$. (or Rana) limnocharis. As clearly shown by Toda et al. (1997), populations from Okinawajima and more northern localities of Japan are genetically very close to some Chinese populations (Wenjiang and Shanghai), that are now split from $F$. limnocharis as a distinct species, $F$. multistriata by Chinese authors. Simply based on literature information, Fei et al. (2002) assigned all Chinese populations to this name, although they admitted possible differentiation among them. Chinese populations assuredly include genetic variations (Toda et al., 1997, 1998a), and it is at present pertinent to restrict populations from Hongkong and adjacent areas (e.g., Guangzhou) as F. multistriata. Furthermore, Dubois and Ohler's (2000) designation of a neotype of $R$. multistriata and its placement in Fejervarya did not mean that the species is distinct from $F$. limnocharis in strict sense. These authors merely gave a description of a single specimen of the neotype, which did not necessarily represent characteristics of a good biological species, and they actually never compared $F$. multistriata with $F$. limnocharis in stating its valid status. Our comparison of the two nominate species in this study first clarified their morphological dissimilarity.

It is clear that the East Asian populations of the $F$. limnocharis complex are different from topotypic $F$. limnocharis as already shown by their great genetic differentiations (Toda et al., 1998a; Djong et al., 2007; Sumida et al., 2007). The taxonomic decision on the South- ern Ryukyu populations could be made simply by their direct comparison with the topotypic F. limnocharis, and without considering taxonomic relationships with surrounding populations other than $F$. multistriata from Hongkong. However, it is obvious that the taxonomic status of populations from Japan mainland, Ryukyu Archipelago other than several southern islands, and Taiwan should be re-evaluated not only by considering relationships among them, but also their relation to the Chinese populations that may include more than one species.

Fejervarya sakishimensis occurs almost all islands of the Southern Ryukyus, from Miyakojima to Yonagunijima Islands. This is unusual among frogs from this region, that are mostly restricted to the two major islands of Ishigakijima and Iriomotejima (e.g., Rana [Odorrana] supranarina, $R$. [O.] utsunomiyaorum, and Rhacophorus owstoni [see Toyama, 1976]), or to these two islands and Taiwan (Rana [Nidirana] okinavana and Kurixalus eiffingeri Boettger, 1895). Like an endemic toad on Miyakojima Island (Bufo gargarizans miyakonis), occurrence of $F$. sakishimensis on this island is notable. It is possible that distribution of this species on the island might have resulted from artificial introduction or overseas dispersal, but the degree of genetic differentiations between the Miyakojima population and the Yaeyama Group populations is not small enough to surmise its very recent invasion to the island (Toda et al., 1997). Thus, the history of $F$. sakishimensis in the Southern Ryukyus, including Miyakojima and adjacent islets, seems fairly long.

It is estimated that the ancestral stock of $F$. sakishimensis, after genetical divergence from the ancestor of the surrounding $F$. limnocharis complex at least by Early Pleistocene, has been isolated in the regions corresponding to the present Southern Ryukyus and Taiwan around the end of Middle Pleistocene (Toda, 1999). This ancestral form of $F$. sakishimensis in Taiwan, however, seems to have been expelled in the region west of the central mountain range by another form of the $F$. 
limnocharis complex, which more recently dispersed to this island from the continent. On the eastern side of the mountain range, descendants of the primary Taiwanese-Southern Ryukyu form still exist, but seem to have been losing the original genetic structure through the genetic amalgamation with the new arriver (Toda et al., 1998b; Toda, 1999). Taxonomic treatment of the Eastern Taiwanese population should, therefore, be carefully considered, particularly in relation to $F$. sakishimensis. Further detailed genetic and morphological studies are desired to draw a convincing conclusion on this problem.

\section{ACKNOWLEDGMENTS}

We thank S.-L. Cheng, T. Hikida, M. Hinoue, Y. Hokama, N. Kamezaki, S. Katsuren, N. Maeda, G. Masunaga, M.-T. Matsui, K. Shimamura, S. Tanaka, M. Toyama, and T. Utsunomiya for help in collecting specimens, and K. Nishikawa for help in preparing a figure. M. Matsui thanks late K. Koba for help in obtaining valuable literature, and C. McCarthy and B. T. Clarke (BM), G. Koehler (SMF), R. Günther and U. Manthey (ZMB), and A. Dubois and A. Ohler (MNHNP) for allowing him to examine type specimens under their care. This study was supported by a grant under The Monbu-sho International Scientific Research Program (No. 10041166 to M. Matsui), a grant from the US National Geographic Society (No. 4505-91 to M. Matsui), and a grant for the 21 st Century COE Program (K-23; to University of the Ryukyus to H. Ota) from the Monbu-kagaku-sho.

\section{LITERRATURE CITED}

Boulenger, G. A. 1920. A monograph of the South Asia, Papuan, Melanesian, and Australian frogs of the genus Rana. Rec. Indian Mus. 20: 1226.

DJong, T. H., M. M. Islam, M. Nishioka, M. Matsui, H. OtA, M. KuRAmoto, M. M. R. Khan, M. S. Alam, A. De Silva, W. Khonsue, AND M. SUMIDA. 2007. Genetic relationships and reproductive isolation mechanism among the Fejervarya limnocharis complex from Indonesia (Java) and other Asian countries. Zool. Sci. 24: 360-375.

DuBoIS, A. 1975. Un nouveau complexe d'especes jumelles distinguées par le chant: les grenouilles du Nepal voisines de Rana limnocharis Boie (Amphibiens, Anoures). C. R. Acad. Sc. Paris, Sér. D. 281: 1717-1720.

DuBoIS, A. 1984. Note préliminaire sur le groupe de Rana limnocharis Gravenhorst, 1829 (amphibiens, anoures). Alytes 3(4): 143-159.

DuboIS, A. AND A. OHLER. 2000. Systematics of Fejervarya limnocharis (Gravenhorst, 1829) (Amphibian, Anura, Ranidae) and related species. 1. Nomenclatural status and type-specimens of the nominal species Rana limnocharis Gravenhorst, 1829. Alytes 18(1/2): 15-50.

DutTA, S. K. 1997. A new species of Limnonectes (Anura: Ranidae) from Orissa, India. Hamadryad 22(1): 1-8.

FEI, L., C.-Y. YE, N.-P. JIANG, AND F. XIE. 2002. On taxonomic status of Rana limnocharis group with revision of nomenclature of the rice frog from China. Herpetol. Sinica 9: 88-96. (in Chinese with English summary)

IKEHARA, S., Y. YoNASHIRO, K. MiYAGI, AND M. TOYAMA. 1984. Land Vertebrates. Shinsei-Tosho, Naha. (in Japanese)

INGER, R. F. 1947. Preliminary survey of the amphibians of the Riukiu Islands. Fieldiana: Zool. 32: 297-352.

INGER, R. F. 1954. Systematics and zoogeography of Philippine Amphibia. Fieldiana: Zool. 33: 181-531.

INGER, R. F. 1966. The systematics and zoogeography of the Amphibia of Borneo. Fieldiana: Zool. 52: $1-402$.

KAMPEN, P. N. VAN. 1923. The Amphibia of the Indo-Australian Archipelago. E. J. Brill, Leiden.

KIMURA, M. 1980. A simple method for estimating evolutionary rates of base substitutions through comparative studies of nucleotide sequences. J. Mol. Evol. 16: 111-120.

KuRAmoto, M. 1967. Studies on Rana limnocharis Boie I. Population hybrids and embryonic temperature tolerances. Bull. Fukuoka Univ. Educ. Pt. 3 17: 103-110. 
KuRAmoto, M. 1968. Studies on Rana limnocharis Boie II. Geographic variation in external characters. Bull. Fukuoka Univ. Educ. Pt. 3 18: 109-119.

KuRAmoto, M. 1971. Studies on Rana limnocharis Boie IV. Karyotypic differentiation of subspecies. Bull. Fukuoka Univ. Educ. Pt. 3 20: 105-111.

KuRAMOTO, M. 1973. The amphibians of Iriomote of the Ryukyu Islands: ecological and zoogeographical notes. Bull. Fukuoka Univ. Educ. Pt. 3 22: 139-151.

KuRAMOTO, M. 1979. Distribution and isolation in the anurans of the Ryukyu Islands. Jpn. J. Herpetol. 8: 8-21. (in Japanese with English abstract)

MAedA, N. AND M. MATSUI. 1989. Frogs and Toads of Japan. Bun-ichi Sogo Shuppan, Tokyo.

MAEDA, N. AND M. MATSUI. 1999. Frogs and Toads of Japan. Revised edition. Bun-ichi Sogo Shuppan, Tokyo.

MATSUI, M. 1984. Morphometric variation analyses and revision of the Japanese toads (Genus Bufo, Bufonidae). Contrib. Biol. Lab., Kyoto Univ. 26: 209-428.

Matsui, M., H. Ito, T. Shimada, H. OtA, S. K. Saidapur, W. Khonsue, T. TANaka-Ueno, AND G.-F. WU. 2005. Taxonomic relationships within the Pan-Oriental narrow-mouth toad Microhyla ornata as revealed by mtDNA analysis (Amphibia, Anura, Microhylidae). Zool. Sci. 22: 489-495.

MORI, A. AND H. MORIGUCHI. 1988. Food habits of the snakes in Japan: a critical review. The Snake 20: 98-113.

NAKAMURA, K. AND S.-I. UÉNO. 1963. Japanese Reptiles and Amphibians in Colour. Hoikusha, Osaka. (in Japanese)

NEI, M. 1972. Genetic distance between populations. Am. Nat. 106: 283-292

NEI, M. 1978. Estimation of average heterozygosity and genetic distance from a small number of individuals. Genetics 89: 583-590.

NisHIOKA, M. AND M. SUMIDA. 1990. Differentiation of Rana limnocharis and two allied species elucidated by electrophoretic analysis. Sci. Rep. Lab. Amphib. Biol., Hiroshima Univ. 10: 125154.

Nohina, S., M. Toyama, Y. Yasukawa, S.-L.
Chen, K. TAKahashi, AND K. Kugai. 1998. A preliminary survey of the terrestrial reptiles and amphibians in the Miyako Group, Ryukyu Archipelago. Bull. Hirara City Mus. (5): 23-38. (in Japanese with English abstract)

OKADA, Y. 1930. A Monograph of the Japanese Tailless Batrachians. Iwanami-shoten, Tokyo. (in Japanese)

OKADA, Y. 1931. The Tailless Batrachians of the Japanese Empire. Imp. Agr. Exper. Station, Tokyo.

OKADA, Y. 1966. Fauna Japonica, Anura (Amphibia). Tokyo Electr. Engin. Coll. Press, Tokyo.

OTA, H. 1981. Notes on the herpetofauna of Hateruma Island, Ryukyu Archipelago. Jpn. J. Herpetol. 9(2): 54-60. (in Japanese with English abstract)

OTA, H. 1983. On the herpetofauna of the Yaeyama Group, Ryukyu Archipelago (I). Biol. Mag. Okinawa (21): 13-19. (in Japanese with English abstract)

Ota, H., M. Toda, G. Masunaga, A. KikuKawa, AND M. TODA. 2004. Feral populations of amphibians and reptiles in the Ryukyu Archipelago, Japan. Glob. Envir. Res. 8: 133-143.

SANO, K. 2003. Breeding biology of the Ryukyu crested serpent eagle in Ishigaki island, Okinawa. Strix. 21: 141-150. (in Japanese with English abstract)

SAvaGe, J. M. 1975. Systematics and distribution of the Mexican and Central American stream frogs related to Eleutherodactylus rugulosus. Copeia 1975: 254-306.

STEJNEGER, L. 1907. Herpetology of Japan and adjacent territory. Bull. U. S. Natl. Mus. 58: 1577.

STUART, B. L., R. F. INGER, AND H. K. VORIS. 2007. High level of cryptic species diversity revealed by sympatric lineages of Southeast Asian forest frogs. Biol. Let. 2: 470-474.

SUMIDA, M., Y. KONDO, Y. KANAMORI, AND M. NISHIOKA. 2002. Inter- and intraspecific evolutionary relationships of the rice frog Rana limnocharis and the allied species $R$. cancrivora inferred from crossing experiments and mitochondrial DNA sequences of the 12S and 16S rRNA genes. Mol. Phylogenet. Evol. 25: 293305. 
SumidA, M., M. Kotaki, M. M. ISlam, T. H. DJong, T. IgawA, Y. Kondo, M. MAtsui, A. De Silva, W. Khonsue, AND M. NishioKA. 2007. Evolutionary relationships and reproductive isolating mechanisms in the rice frog (Fejervarya limnocharis) species complex from Sri Lanka, Thailand, Taiwan and Japan, inferred from mtDNA gene sequences, allozymes, and crossing experiments. Zool. Sci. 24: 547-562.

TODA, M. 1999. Historical biogeography of East Asian populations of Rana limnocharis (Amphibia: Anura): A review. p. 299-315. In: H. Ota (ed.), Tropical Island Herpetofauna: Origin, Current Diversity, and Conservation. Elsevier, Amsterdam.

TodA, M., M. NishidA, M. Matsui, G.-F. Wu, AND H. OTA. 1997. Allozyme variation among east Asian populations of the Indian rice frog, Rana limnocharis (Amphibia: Anura). Biochem. Syst. Ecol. 25(2): 143-159.

TODA, M., M. MATSUI, M. NishidA, AND H. OTA. 1998a. Genetic divergence among Southeast and East Asian populations of Rana limnocharis (Amphibia: Anura), with special reference to sympatric cryptic species in Java. Zool. Sci. 15: 607-613.

TodA, M., M. NishidA, M. MATSUi, K.-Y. LuE, AND H. OTA. 1998b. Genetic variation in the Indian rice frog, Rana limnocharis (Amphibia: Anura), in Taiwan, as revealed by allozyme data.
Herpetologica 54(1): 73-82.

TOYAMA, M. 1976. On the herpetofauna of the Miyako Islands, Ryukyu Archipelago (I). Jpn. J. Herpetol. 6(3): 64-74. (in Japanese with English abstract)

TOYAMA, M. 1981. Herpetofauna of the Miyako Group. Okiseikyouken-Kaishi (14): 30-39. (in Japanese)

UTSUNOMIYA, T. 1979. Rana limnocharis. P. 154155. In: S. Sengoku (ed.), Amphibians/Reptiles in Colour. Ie-no-Hikari-Kyokai, Tokyo. (in Japanese)

Veith, M., J. Kosuch, A. OHLer, AND A. Dubois. 2001. Sysytematics of Fejervarya limnocharis (Gravenhorst, 1829) (Amphibia, Anura, Ranidae) and related species. 2. Morphological and molecular variation in frogs from the Greater Sunda Islands (Sumatra, Java, Borneo) with the definition of two species. Alytes 19(1): 5-28.

Watanabe, S. AND M. IzAwA. 2005. Species composition and size structure of frogs preyed by the Iriomote cat Prionailurus bengalensis iriomotensis. Mammal Study 30: 151-155.

WATANABE, S., N. NAKANiShI, AND M. IZAwA. 2005. Seasonal abundance in the floor-dwelling frog fauna on Iriomote Island of the Ryukyu Archipelago Japan. J. Tropical Ecol. 21: 85-91.

Accepted: 18 November 2007 